\title{
Adsorptive Removal of Malachite Green from Model Aqueous Solutions by Chemically Modified Waste Green Tea Biomass
}

\author{
Cerasella Indolean, ${ }^{* 1}$ Silvia Burcă ${ }^{1}$ and Andrada Măicăneanu ${ }^{* 2}$ \\ ${ }^{1}$ Department of Chemical Engineering, Babeş-Bolyai University, 11 Arany Janos st., RO-400028, Cluj-Napoca, Romania \\ ${ }^{2}$ Department of Chemistry, Indiana University of Pennsylvania, Indiana, PA 15705, USA \\ *Corresponding author: E-mail: cella@chem.ubbcluj.ro; sanda.maicaneanu@iup.edu \\ tel: +40264593833 ext. 5761. fax: +40264590818
}

Received: 08-02-2017

\begin{abstract}
The adsorption of malachite green (MG) from aqueous solution by waste green tea (WGT) biomass was investigated. A series of experiments in batch conditions were conducted in order to assess the MG removal on WGT, following adsorbent quantity and temperature influences. Maximum removal efficiency for untreated WGT was $89 \%$ (4 g biomass, 100 $\mathrm{mL}$ solution of $94 \mathrm{mg} / \mathrm{L}, 316 \mathrm{~K}$ ). It was found that the adsorption of MG increased by increasing temperature from 296 to $316 \mathrm{~K}$. Thermodynamic parameters $\left(\Delta \mathrm{H}^{\circ}, \Delta \mathrm{S}^{\circ}, \Delta \mathrm{G}^{\circ}\right)$ were calculated, and indicated that dye adsorption onto the studied biomass was endothermic and non-spontaneous. Six chemical treatments were tested (four acidic $-\mathrm{H}_{3} \mathrm{PO}_{4}, \mathrm{H}_{2} \mathrm{SO}_{4}$, $\mathrm{HCl}$, and tartaric acid, one oxidant $-\mathrm{H}_{2} \mathrm{O}_{2}$, and one basic $-\mathrm{NaOH}$ ) in order to study the chemical groups responsible for MG adsorption onto WGT biomass. The alkali and acidic treatments led to an increase of adsorption efficiency up to 92\% and $95 \%\left(\mathrm{H}_{2} \mathrm{SO}_{4}\right)$ respectively. The FTIR spectroscopy results emphasized the modifications of the biomass surface and how these are influencing the adsorption process.
\end{abstract}

Keywords: Waste green tea, chemical treatment, adsorption, malachite green, SEM analysis

\section{Introduction}

Dyes are usually used in industries such as textile, paper, drug, rubber, food, cosmetic, plastic, printing, etc., activities, which have as result considerable amount of colored wastewater. Dye is the first contaminant to be recognized in wastewater, because not only damage the aesthetic nature of freshwater, which will reduce sun penetration, but also many of them possess a serious threat for human beings, aquatic life, and for environment, in generall. ${ }^{1}$

The presence of very small amounts of dyes in water (less than $1 \mathrm{ppm}$ for some dyes) is highly visible and undesirable. $^{2}$ Thus, the development of clean-up technologies for the treatment of water contaminated with dyes is of major interest. ${ }^{3}$ A number of technologies are available to control and reduce the water pollution with dye contaminants. Among them are coagulation ${ }^{4}$, filtration ${ }^{5}$, ionexchange, ${ }^{6}$ electrolysis, ${ }^{7}$ advanced oxidation processes ${ }^{8}$, foam flotation, ${ }^{9}$ etc. The removal of dyes in an economic way remains an important problem, although a number of systems have been developed using adsorption techniques. ${ }^{10}$ Adsorption is a well-known equilibrium separation process and an effective method for water decontamination applications. Among many techniques for water re-use, adsorption has been found to be superior in terms of ease of operation, low initial cost, flexibility and simplicity of design, and insensitivity to toxic pollutants. ${ }^{11}$ Also, adsorption does not result in the formation of harmful substances due to partial degradation as some chemical or biological methods would. ${ }^{12}$ Adsorption of most of the adsorbents including agricultural by-product is controlled by physical forces, with some exception of chemisorption. ${ }^{1}$ The main physical forces controlling adsorption are van der Waals forces, hydrogen bonds, dipole-dipole $\pi-\pi$ interactions, etc. ${ }^{13}$

Many low-cost adsorbents, such as rice husk, wheat bran, coconut bunch waste, orange peel, banana peel, garlic peel, papaya seed, pineapple stem waste, sunflower stalks, silk cotton hull, maize cob, etc., which are able to 
bind dyes molecules, have been previously researched and evaluated. $^{14}$

Waste green tea could be also an economical alternative for dyes removal from wastewater. Tea plant, called Camellia sinensis, ${ }^{15}$ is native to South-East Asia, but is cultivated today in over 30 countries in several areas of the world and belongs to the genus Camellia, Theaceae family. ${ }^{16}$ Taking into consideration the quantity of tea and tea based drinks consumed annualy, which gives rise to a disposal problem, utilization of such waste is extremely desirable. $^{17-18}$

The cell wall of tea consist of cellulose and hemicelluloses, lignin, condensed tannins, and structural proteins. In short, tea waste have a good potential as dyes scavengers from aquesous solution since its constituents contain several functional groups. ${ }^{19}$ Previous studies have centered their attention on the preparation of waste tea activated carbon ${ }^{17,20}$ or on various treatments involving acetylation, isopropyl alcohol, formaldehyde, $\mathrm{HNO}_{3}$, pressure, and ultrasound. ${ }^{17,20-24}$

The aim of this study was to realize malachite green (MG) adsorption onto chemically modified waste green tea (WGT). Influence of the adsorbent quantity and temperature over the MG removal were also considered in order to investigate the WGT potential as a biosorbent. Influence of carboxyl, carbonyl, sulfonate, sulfhydryl, phosphate, and hydroxyl groups from the biomass surface over the adsorption of MG onto untreated and chemically modified WGT were detailed. Equilibrium and kinetic studies on the untreated WGT - MG system were considered in a previous paper. ${ }^{25}$

\section{Materials and Methods}

\section{1. Adsorbent}

The adsorbent, WGT, was collected from a local tea shop. The used green tea leaves were washed several times with distilled water to remove any adhering dirt and repeatedly boiled in distilled water until the filtered water was clear. Then it was oven dried at $80{ }^{\circ} \mathrm{C}$ for $48 \mathrm{~h}$. Finally, the WGT sample was ground and sieved to obtain grains in the 200-400 $\mu \mathrm{m}$ range that will be further used in the adsorption experiments.

\section{2. Characterization of the Biosorbent}

\section{2. 1. Elemental Analysis}

In order to obtain information about the elemental composition of the studied materials, the C, H, N, S, and $\mathrm{O}$ content of untreated and chemically modified WGT, before and after MG adsorption (for all considered treatments) was determined. Elemental analysis was carried out using Thermo Finnigan Flash EA 1112 Series equipment. The biosorbent sample was added into a tin capsule and analysed at $900{ }^{\circ} \mathrm{C}$ under $\mathrm{O}_{2}$ atmosphere.

\section{2. 2. SEM Analysis}

Scanning electron microscope images were obtained with a JEOL (USA) JSM 5510 LV apparatus on samples coated with a thin layer of gold under vacuum to improve electron conductivity and image quality.

\section{3. Preparation of MG Solutions}

MG, $N, N, N^{\prime}, N^{\prime}$-Tetramethyl-4,4'-diaminotriphenylcarbenium oxalate, is a cationic (basic) dye ${ }^{26}$ which has a positive charge that is delocalized on the entire compound by resonance. It belongs to triphenylmethanes family and is amphipathic (behaves as a polar and non-polar compound). MG is commonly used for dyeing textiles and paper, as well as is an antiparasitic and antifungal agent in aquaristics. $^{14}$

Malachite green was purchased from Penta (Czech Republic) and used without further purification. Stock solution $(1000 \mathrm{mg} / \mathrm{L})$ of $\mathrm{MG}$ were prepared using distilled water and stored in the refrigerator. Experiments were carried out using solutions obtained by dillution of the stock solution to the desired concentration. MG concentration was determined using a double beam UV-visible spectrophotometer (GBC Cintra 202) at $\lambda=618 \mathrm{~nm}$.

\section{4. Adsorption Experiments}

Adsorption process was conducted in batch conditions, in dynamic regime (magnetic stirring at $300 \mathrm{rpm}$ ), through the contact of a certain amount of adsorbent (1-5 $\mathrm{g}$ ) with a volume of $100 \mathrm{~mL} \mathrm{MG}$ dye aqueous solution 94 $\mathrm{mg} / \mathrm{L}$. The adsorption process was realized until equilibrium was reached (240 min, established from preliminary experiments). Residual dye concentration in solution was determined, at established time intervals after a preliminary centrifugation (5 min at $10000 \mathrm{rpm}$ ) and appropriate dilution.

In order to determine the effect of temperature on the adsorption process, experiments were caried out at three different temperatures 296,306 , and $316 \mathrm{~K}$. The experiments were realized using $100 \mathrm{~mL}$ solution of 94 $\mathrm{mg} / \mathrm{L}$ and $4 \mathrm{~g}$ WGT.

Adsorption efficiency expressed as percentage was calculated with equation (1): ${ }^{27,28}$

$$
E=\frac{C_{0}-C_{e}}{C_{0}} \cdot 100
$$

where, $\mathrm{C}_{0}$ and $\mathrm{C}_{\mathrm{e}}$ are $\mathrm{MB}$ initial and equilibrium concentrations, respectively $(\mathrm{mg} / \mathrm{L})$.

The amount of the adsorbed dye (MG) onto the WGT biomass was expressed as adsorption capacity $\left(\mathrm{q}_{\mathrm{e}}\right.$, $\mathrm{mg} / \mathrm{g}$ ) and calculated as shown in equation (2): ${ }^{16,27}$

$$
q_{e}=\frac{\left(C_{0}-C_{e}\right) \cdot V}{m}
$$

where, $\mathrm{V}$ is solution volume $(\mathrm{L})$, and $\mathrm{m}$ is WGT quantity $(\mathrm{g})$. 
All the experiments were repeated three times, the values presented were calculated using averaged concentration values.

\section{5. Chemical Treatments for WGT Biomass}

\section{5. $1 . \mathrm{H}_{3} \mathrm{PO}_{4}$ Treatment}

$10 \mathrm{~g}$ of WGT were mixed with $50 \mathrm{~mL} 50 \% \mathrm{H}_{3} \mathrm{PO}_{4}$ solution at room temperature for $24 \mathrm{~h}$ in a $500 \mathrm{~mL}$ beaker with a stirring speed of $150 \mathrm{rpm}$ so that the reagent was fully incorporated into the raw material. ${ }^{29}$ After this treatment, the modified WGT was filtered and washed with distilled water several times until $7 \mathrm{pH}$ and filtered. Later on, the adsorbent was oven-dried at $105{ }^{\circ} \mathrm{C}$ for $12 \mathrm{~h}$.

\section{5. 2. $\mathrm{H}_{2} \mathrm{SO}_{4}$ Treatment (Preparation of Activated Carbon from WGT)}

The activated carbon was prepared by contacting WGT with $\mathrm{H}_{2} \mathrm{SO}_{4} 98 \%$ for $24 \mathrm{~h}$ (1:1 acid volume to WGT weight). After that, the charred material was washed several times in distilled water until the $\mathrm{pH}$ of the solution becomes neutral. ${ }^{30,31}$ Chemical treated WGT was dried first in air, overnight, and then in an oven at $90-100{ }^{\circ} \mathrm{C}$ for $8-10$ hours.

\section{5. 3. HCl Treatment}

$10 \mathrm{~g}$ of WGT were slowly stirred $(150 \mathrm{rpm})$ in 100 $\mathrm{mL} \mathrm{HCl} 1 \mathrm{~N}$ for 4 hours. The treated cellulosic WGT was left overnight in contact with $\mathrm{HCl}$ solution and thereafter was washed with distilled water several times until neutral $\mathrm{pH}$ and filtered. The HCl-treated WGT biomass was dried in a hot air oven at $80^{\circ} \mathrm{C}$ until constant weight (24 hours).

\section{5. 4. Tartaric Acid Treatment}

$15 \mathrm{~g}$ of WGT were mixed with $100 \mathrm{~mL}$ of $2 \mathrm{M}$ tartaric acid. The mixture was stirred at $200 \mathrm{rpm}$ for 4 hours. The modified WGT was subsequently washed with distilled water until neutral and filtered. The treated WGT was dried at $80{ }^{\circ} \mathrm{C}$ for $24 \mathrm{~h}$.

\section{5. 5. $\mathrm{H}_{2} \mathrm{O}_{2}$ Treatment}

$10 \mathrm{~g}$ of WGT were mixed with $50 \mathrm{~mL}$ of $25 \% \mathrm{H}_{2} \mathrm{O}_{2}$ and kept in contact for $3 \mathrm{~h}$ at room temperature, in a closed vessel and then boiled for $15 \mathrm{~min}$. The sample was washed with distilled water to neutral $\mathrm{pH}$, filtered and dried in an oven at $80{ }^{\circ} \mathrm{C}$ until constant weight. ${ }^{32}$

\section{5. 6. NaOH Treatment}

$10 \mathrm{~g}$ of WGT were mixed with $150 \mathrm{~mL} 1 \% \mathrm{NaOH}$ solution for $6 \mathrm{~h}$ at room temperature. ${ }^{30}$ The cellulosic sample was then washed thoroughly with distilled water until the sample was neutralized and dried in the oven at $80{ }^{\circ} \mathrm{C}$ for $24 \mathrm{~h}$.

The material obtained after each individual chemical treatment was grounded and passed through several sieves in order to obtain the desired particle size (200-400 $\mu \mathrm{m})$. Finally, the resulting material was stored in airtight containers for further use.

\section{6. FTIR Analysis}

The FTIR spectra (1.2 mg WGT samples mixed with $300 \mathrm{mg} \mathrm{KBr}$ ) were obtained using JASCO 615 FTIR spectrometer, 500-4000 $\mathrm{cm}^{-1}$, resolution $2 \mathrm{~cm}^{-1}$.

\section{Results and Discussion}

\section{1. Elemental Analysis}

Untreated and chemically treated WGT elemental analysis performed before and after MG adsorption showed that after treatment, in some cases (exception acidic treatments with $\mathrm{H}_{3} \mathrm{PO}_{4}, \mathrm{H}_{2} \mathrm{SO}_{4}$, and tartaric acid), carbon content deacreses from the initial $52.27 \%$ (untreated WGT) to values ranging from $44.83 \%$ for $\mathrm{NaOH}$ treatment to $45.80 \%$ for $\mathrm{H}_{2} \mathrm{O}_{2}$, Table 1 . The organic content of the material decreases significantly due to the delignification process that takes place. ${ }^{32}$ In the case of $\mathrm{H}_{2} \mathrm{SO}_{4}$ treatment, carbon content increases to $56.83 \%$ due to the formation of a new active carbon material (biochar). Elemental analysis of WGT samples after MG adsorption showed an increase of the carbon content in all cases, confirming the fact that organic dye is adsorbed onto the surface of the studied materials.

\section{2. SEM Analysis}

The surface morphology of untreated WGT, before (a) and after (b) adsorptive removal of MG was determined by SEM and is presented in Figure 1.

The raw WGT surface is shown to be rough and consists of many strands of fibrous-like materials (Figure 1a).

SEM image confirmed the amorphous and heterogeneous structure of WGT. Considerable changes in surface morphology after biosorption are noted as surface protuberances become less obvious and the surface becomes smoother (Figure 1b).

\section{3. The Effect of Adsorbent Quantity}

The adsorption of MG onto WGT was investigated by changing the adsorbent quantity, from 1 to $5 \mathrm{~g}$, using particles of 200-400 $\mu \mathrm{m}$ in diameter, $100 \mathrm{~mL}$ dye aqueous solution, $94 \mathrm{mg} / \mathrm{L}$, magnetic stirring $(300 \mathrm{rpm})$, for 240 minutes, until the equilibrium was reached, Figure 2.

As presented in Figure 3 with the increasing amount of adsorbent the adsorption efficiency increase too, due to 
Table 1. Elemental analysis of WGT untreated and chemically modified, before and after MG adsorption (1\% error)

\begin{tabular}{llcccc}
\hline Nr. crt. & Component & $\mathbf{C}(\%)$ & $\mathbf{H}(\%)$ & $\mathbf{N}(\%)$ & $\mathbf{O}^{*}(\boldsymbol{\%})$ \\
\hline 1 & WGT untreated - before adsorption & 52.27 & 6.31 & 3.86 & 37.56 \\
2 & WGT untreated - after adsorption & 53.71 & 5.92 & 3.26 & 37.11 \\
3 & WGT treated with $\mathrm{H}_{3} \mathrm{PO}_{4}$ - before adsorption & 54.06 & 3.56 & 1.76 & 40.62 \\
4 & WGT treated with $\mathrm{H}_{3} \mathrm{PO}_{4}$ - after adsorption & 58.78 & 4.07 & 2.47 & 34.98 \\
5 & WGT treated with $\mathrm{H}_{2} \mathrm{SO}_{4}$ - before adsorption & 56.83 & 5.64 & 3.46 & 34.07 \\
6 & WGT treated with $\mathrm{H}_{2} \mathrm{SO}_{4}$ - after adsorption & 60.26 & 5.72 & 3.86 & 30.16 \\
7 & WGT treated with $\mathrm{HCl}$ - before adsorption & 48.19 & 6.59 & 3.67 & 41.55 \\
8 & WGT treated with $\mathrm{HCl}$ - after adsorption & 49.71 & 6.60 & 4.30 & 39.39 \\
9 & WGT treated with tartaric acid - before adsorption & 53.23 & 6.26 & 3.34 & 37.17 \\
10 & WGT treated with tartaric acid - after adsorption & 54.07 & 6.49 & 4.13 & 35.31 \\
11 & WGT treated with $\mathrm{H}_{2} \mathrm{O}_{2}$ - before adsorption & 45.80 & 6.28 & 3.71 & 44.21 \\
12 & WGT treated with $\mathrm{H}_{2} \mathrm{O}_{2}$ - after adsorption & 46.13 & 6.15 & 3.93 & 43.79 \\
13 & WGT treated with $\mathrm{NaOH}_{-}$before adsorption & 44.83 & 6.13 & 3.28 & 45.76 \\
14 & WGT treated with $\mathrm{NaOH}$ - after adsorption & 48.25 & 6.34 & 3.09 & 42.32 \\
\hline
\end{tabular}

* Calculated by difference
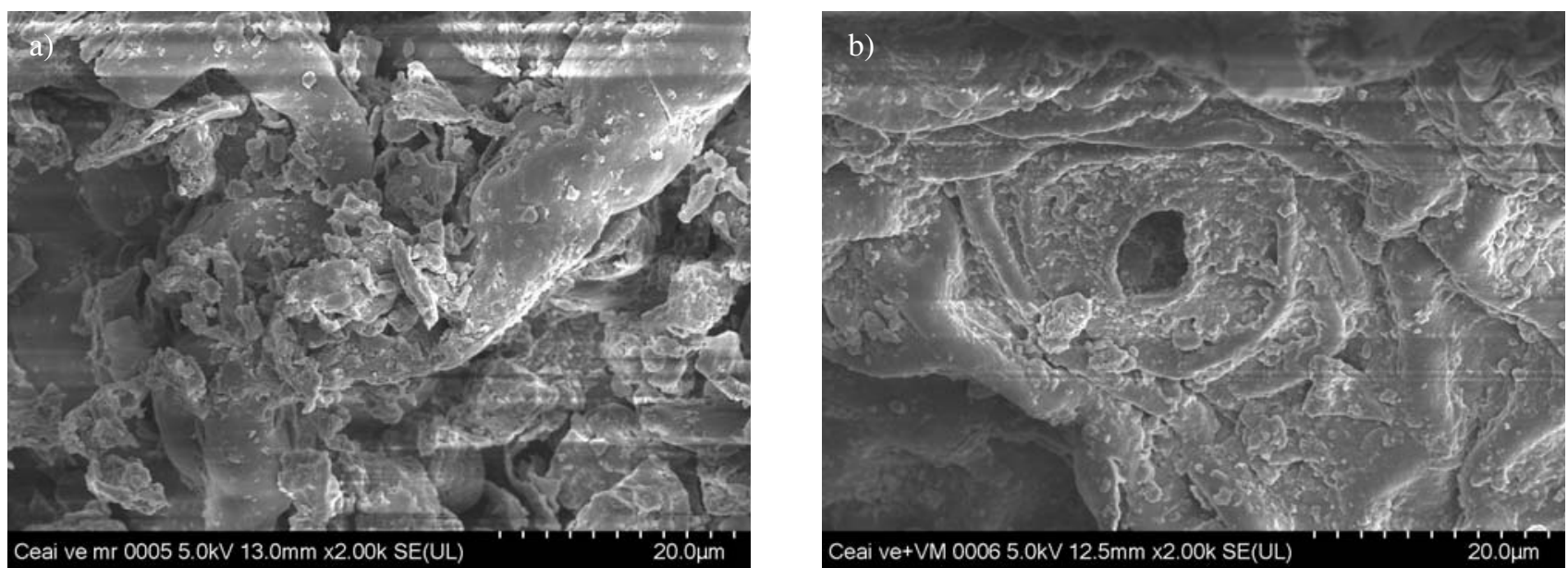

Figure 1. Scanning electron micrographs of untreated WGT before (a) and after (b) adsorptive removal of MG.

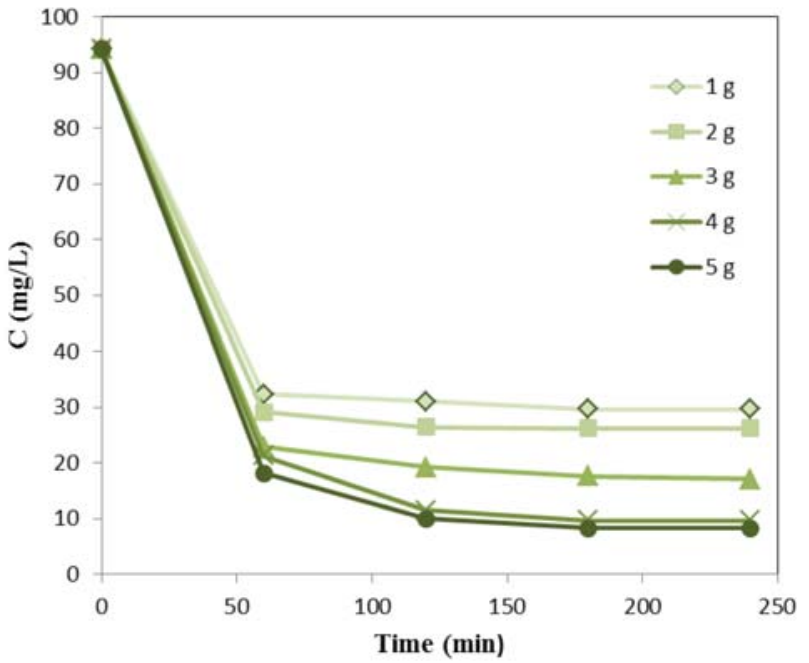

Figure 2. Influence of the WGT quantity (untreated) over the evolution of concentration in time $(296 \mathrm{~K}, 94 \mathrm{mg} / \mathrm{L}, 100 \mathrm{~mL}, 200-400$ $\mu \mathrm{m}, 300 \mathrm{rpm}, 240 \mathrm{~min})$.

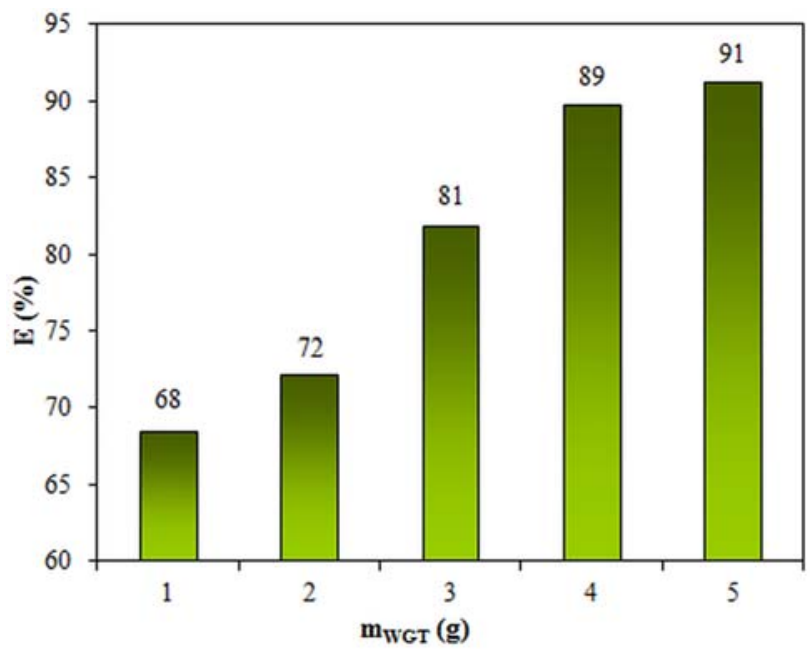

Figure 3. The effect of untreated WGT quantity over the adsorption efficiency $(296 \mathrm{~K}, 94 \mathrm{mg} / \mathrm{L}, 100 \mathrm{~mL}, 200-400 \mu \mathrm{m}, 300 \mathrm{rpm}, 240$ $\min )$. 
an increase of surface area and the availability of more adsorption sites, with more active functional groups. ${ }^{16,27}$

Taking into consideration that by changing the WGT quantity, from 4 to $5 \mathrm{~g}$, the increase in adsorption efficiency is small $\left(\mathrm{E}_{4 \mathrm{~g}}=89 \%\right.$ and $\left.\mathrm{E}_{5 \mathrm{~g}}=91 \%\right)$, and that higher quantities are difficult to handle in terms of sampling and separation from the aqueous solution, further experiments were carried on using $4 \mathrm{~g}$ of WGT.

\section{4. The Effect of Temperature}

It well known that temperature plays an important role in the adsorption processes. A study of temperature dependence for the adsorption process gives valuable information about the enthalpy and entropy changes accompanying the adsorption processes. ${ }^{28}$

The adsorption of MG onto WGT was investigated in the $23-43{ }^{\circ} \mathrm{C}(296-316 \mathrm{~K})$ range. As it can be observed from Figure 4 an increase in temperature led to a higher quantity of dye removed, indicating that in this system adsorption takes place as an endothermic process. Similar findings were reported for other sorbent types. ${ }^{33-36}$

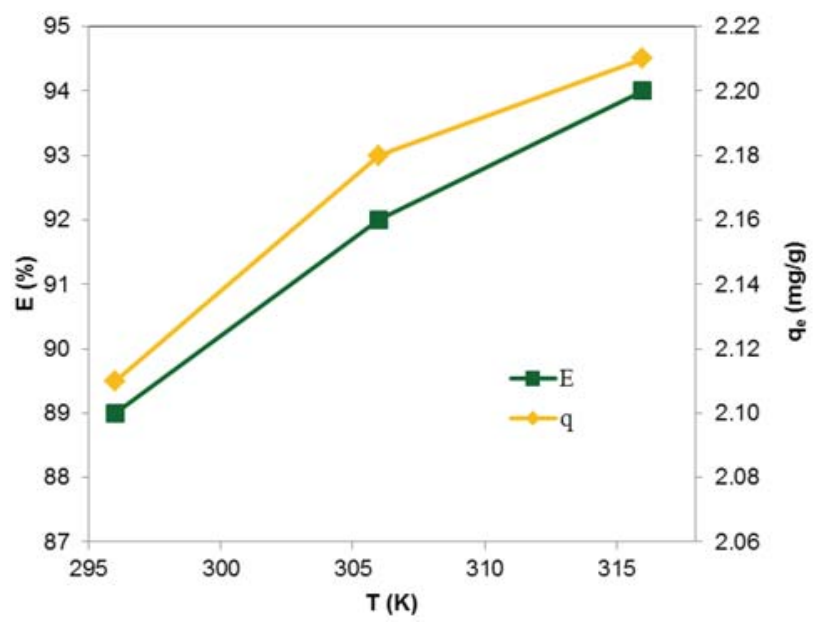

Figure 4. The effect of temperature on MG adsorption onto untreated WGT; $(296 \mathrm{~K}, 94 \mathrm{mg} / \mathrm{L}, 100 \mathrm{~mL}, 4 \mathrm{~g}, 200-400 \mu \mathrm{m}, 300$ rpm, $240 \mathrm{~min})$.

\section{5. Thermodynamic Analysis}

The parameters such as free energy change $\left(\Delta \mathrm{G}^{\circ}\right)$, enthalpy change $\left(\Delta \mathrm{H}^{\circ}\right)$, and enthropy change $\left(\Delta \mathrm{S}^{\circ}\right)$ can be estimated by the change of equilibrium constant with temperature. $^{33}$

The Gibbs free energy change $\left(\Delta \mathrm{G}^{\circ}\right)$ was calculated from equations (3) and (4), while the change of enthalpy $\left(\Delta \mathrm{H}^{\circ}\right)$ and enthropy $\left(\Delta \mathrm{S}^{\circ}\right)$ were obtained using Van’t Hoff equation (5):

$$
\Delta G^{\circ}=\Delta H^{\circ}-T \Delta S^{\circ}
$$

$$
\begin{aligned}
& \Delta G^{\circ}=-R T \ln K_{d} \\
& \ln K_{d}=-\frac{\Delta H^{\circ}}{R T}+\frac{\Delta S^{\circ}}{R}
\end{aligned}
$$

where, $\mathrm{R}$ is the universal gas constant $\left(8.314 \times 10^{-3}\right.$ $\mathrm{kJ} / \mathrm{Kmol})$, $\mathrm{T}$ is absolute temperature $(\mathrm{K})$, and $\mathrm{K}_{\mathrm{d}}$ is the distribution coefficient $\left(\mathrm{K}_{\mathrm{d}}=\mathrm{q}_{\mathrm{e}} / \mathrm{C}_{\mathrm{e}}\right)(\mathrm{L} / \mathrm{g}){ }^{9,37}$

Slope and intercept values of $\ln \left(\mathrm{q}_{\mathrm{e}} / \mathrm{C}_{\mathrm{e}}\right)$ versus $1 / \mathrm{T}$ plot, Figure 5, were used to calculate $\Delta \mathrm{H}^{\circ}$ and $\Delta \mathrm{S}^{\circ}$. The values of the thermodynamic parameters are depicted in Table 2.

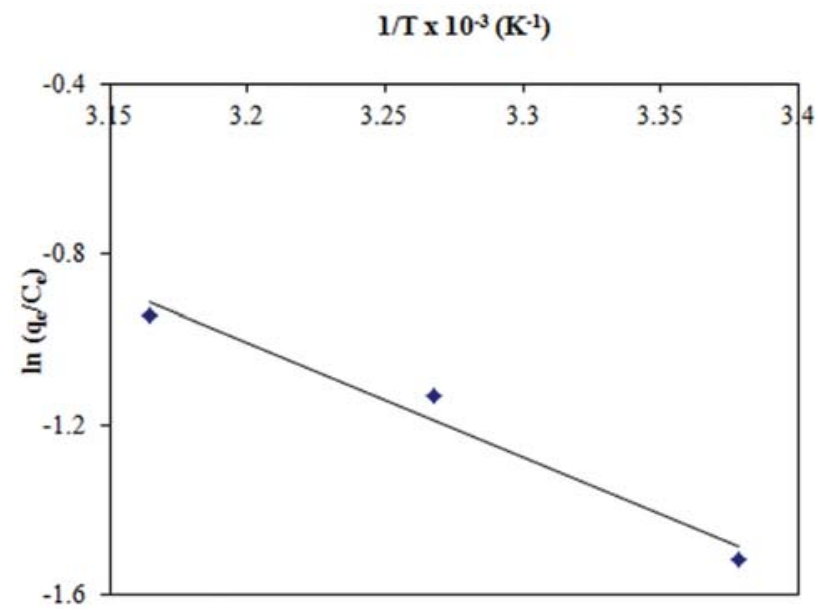

Figure 5. $\ln \left(\mathrm{q}_{\mathrm{e}} / \mathrm{C}_{\mathrm{e}}\right)$ versus $1 / \mathrm{T}$ plot for the estimation of thermodynamic parameters for MG adsorption onto untreated WGT.

The Gibbs free energy, which indicates the degree of spontaneity of the adsorption process, ${ }^{16}$ decreased with increasing of temperature, indicating that a better adsorption is obtained at higher temperatures, and the process is more spontaneous at $316 \mathrm{~K}$. The relativelly small values of $\Delta \mathrm{G}^{\circ}$, although positives, suggested that the adsorption process can be possible in a certain temperature range (between $296-316 \mathrm{~K}$, in the present work). ${ }^{38-40}$

Positive value of $\Delta \mathrm{H}^{\circ}(22.42 \mathrm{~kJ} / \mathrm{kmol})$ shows the endothermic nature of the adsorption. This fact indicates the possibility of physical adsorption, since the heat of chemisorption generally falls into a range of 80-200 $\mathrm{kJ} / \mathrm{mol}^{41}{ }^{41}$ The low value of $\Delta \mathrm{S}^{\circ}$ may imply that no remarcable change in enthropy occurred during the MG adsorption onto WGT. In addition, the positive value of $\Delta \mathrm{S}$ reflects the incresed of randomness at the solid-solution interface during adsorption. ${ }^{42}$

Table 2. Thermodynamic parameters for MG adsorption onto untreated WGT at various temperatures; $(94 \mathrm{mg} / \mathrm{L}, 100 \mathrm{~mL}, 4 \mathrm{~g}$, 200-400 $\mu \mathrm{m}, 300$ rpm, $240 \mathrm{~min}$ ).

\begin{tabular}{ccccc}
\hline$\Delta \mathbf{S}^{\circ}$ & $\Delta \mathbf{H}^{\circ}$ & \multicolumn{3}{c}{$\Delta \mathbf{G}^{\circ}(\mathbf{k J} / \mathbf{m o l})$} \\
$(\mathbf{k J} / \mathbf{m o l ~ K})$ & $(\mathbf{k J} / \mathbf{m o l})$ & $\mathbf{2 9 6 ~ K}$ & $\mathbf{3 0 6 ~ K}$ & $\mathbf{3 1 6 ~ K}$ \\
\hline 0.063 & 22.42 & 3.735 & 3.103 & 2.472 \\
\hline
\end{tabular}




\section{6. The Effect of Chemical Treatments of WGT Biomass Onto MG Adsorption Process}

The influence of chemical treatments on adsorption efficiency of WGT is illustrated in Figure 5.

Generally, the acidic treatments change the negatively charged surface of the WGT biomass to positively charged and thus decrease the electrostatic attractions between biomass surface and the cationic molecules (of MG, for example). ${ }^{43}$ Acid treatments allows the hemicellulose hydrolize, especially xylan present in the lignocelluloses. Hemicelulloses can be degraded into xylose, mannose, acetic acid, galactose, glucose, etc. Phenolic compounds are also formed during acidic treatments from the partial breakdown of lignin. ${ }^{44}$

Tartaric acid treatment of the WGT biomass conducts to an increase of the amount of MG removed from the synthetic wastewater aqueous solutions, this chemical pretreatment converting the biomass to highly adsorbing material in terms of higher percentage of MG removed onto the modified tea surface, probably due to an increase of carboxylic groups number on the WGT surface, result that is in good agreement with others from literature. ${ }^{45,46}$ The adsorption efficiency of MG increases from $89 \%$ (for untreated material) to $93 \%$ (after tartaric acid treatment).

WGT biomass treated with $\mathrm{HCl}$ led to a decrease of adsorption efficiency (from 89\% for untreated material to $75 \%$ for $\mathrm{HCl}$ treatment), fact which can be attributed to the decrease in electronegativity of the biosorbent surface due to the presence of the residual $\mathrm{H}^{+}$ions ${ }^{47,48}$ Due to the fact that generally, the acid treatments lead to a decrease of adsorption, the still high values of adsorption efficiency obtained could be associated with the amount of organic matter present in the treated biomass. ${ }^{49}$

$\mathrm{H}_{3} \mathrm{PO}_{4}$ and $\mathrm{H}_{2} \mathrm{SO}_{4}$ treatments were considered due to the fact that a different material can be obtained, acti-

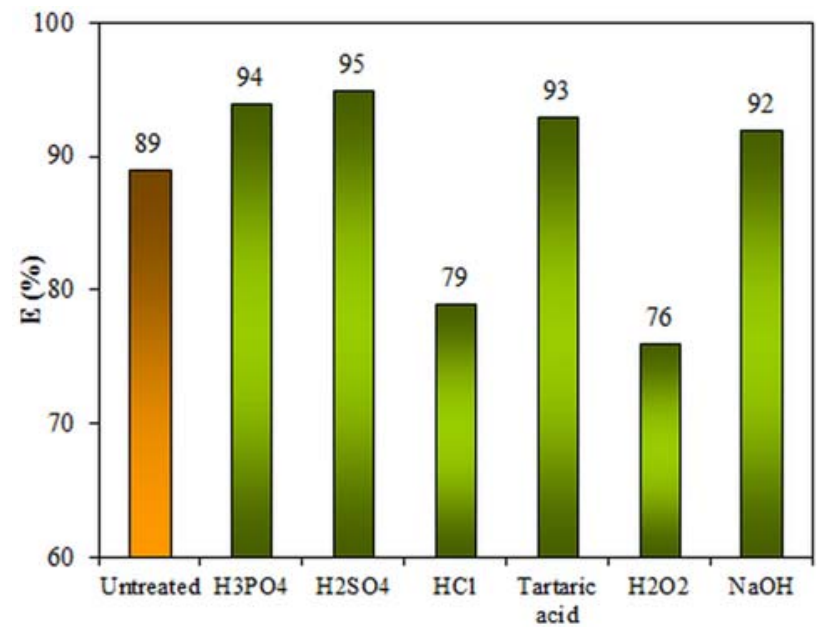

Figure 6. Effect of chemical treatments over the adsorption efficiency of MG onto WGT; (296 K, 94 mg/L, $100 \mathrm{~mL}, 4 \mathrm{~g}, 200-400$ $\mu \mathrm{m}, 300 \mathrm{rpm}, 240 \mathrm{~min})$. vated carbon (or biochar), which is commonly utilized due to its large adsorption capacity, fast adsorption kinetics, and relatively ease of regeneration. ${ }^{19,29}$

The activated carbon obtained from WGT biomass after $\mathrm{H}_{3} \mathrm{PO}_{4}$ and $\mathrm{H}_{2} \mathrm{SO}_{4}$ treatments provided better results for the adsorption efficiency that increases from 89 (for untreated biomass) to 94 , and $95 \%$, respectively (Figure $6)$, results that are in good agreement with other from the literature. $^{16,50}$

In the case of alkali treatment such as $\mathrm{NaOH}$, the increasing of adsorption efficiency can be explained by the fact that after treatment, hydrolysis reactions can occur, causing high dissolution of organic substances from the biomass. ${ }^{43}$ The hydrolysis reactions can lead to the formation of more hydroxylic $\left(\mathrm{HO}^{-}\right)$and carboxylate $\left(\mathrm{COO}^{-}\right)$ groups in the treated biomass, which enhance the cationic adsorption..$^{51}$ The mechanism of alkali treatment is believed to be saponification of intramolecular ester bonds crosslinking xylan hemicellulose and other component, for exemple, lignin. ${ }^{43}$ Dilute $\mathrm{NaOH}$ treatment of lignicellulosic materials caused swelling, leading to a decrease in the degree of polymerization, a decrease in crystallinity, separation of structural linkages between lignin and carbohydrates, and disruption of the lignin structure. ${ }^{30}$

After $\mathrm{NaOH}$ treatment, theWGT biomass had a better adsorption efficiency, an increase from 89 to $92 \%$ was noted. This treatment is very efficient, with a high increase in adsorption efficiency, fact that can be attributed to the changes on the biomass surface (increase in surface area, average pore volume, and pore diameter), ${ }^{52}$ in addition to the already described effects of alkali treatment. $^{30,43,47,51}$

As it can be see in Figure 6, the treatment of WGT biomass with $\mathrm{H}_{2} \mathrm{O}_{2}$ leads to a decrease in efficiency ( $76 \%$ by comparison with $89 \%$ for the untreated material), fact that confirm the hypothesis that if the concentration of oxidant agent is high $\left(25 \% \mathrm{H}_{2} \mathrm{O}_{2}\right)$, the modification of functional groups of the basic structure of the material takes place and the delignification of cellulosic WGT begins to occur. ${ }^{53}$

\section{7. Fourier Transform Infrared Spectroscopy (FTIR)}

FTIR analysis is an important method for identifying the functional groups responsible for the retention of the dye molecules onto biomass surface. FTIR spectra were obtained for MG dye removal instead of onto untreated (Figure 7) and $\mathrm{NaOH}$ treated (Figure 8), before and after biosorption.

The increasing, decreasing, and shifted signals corresponding to different functional groups, were interpreted to indicate which groups participated in the adsorption process. The fact that no significant reduction in number of bands after adsorption for both untreated and treated WGT (Figures 7 and 8) was observed, could indicate that the studied process occurs mainly as physisorption ). ${ }^{32}$ 


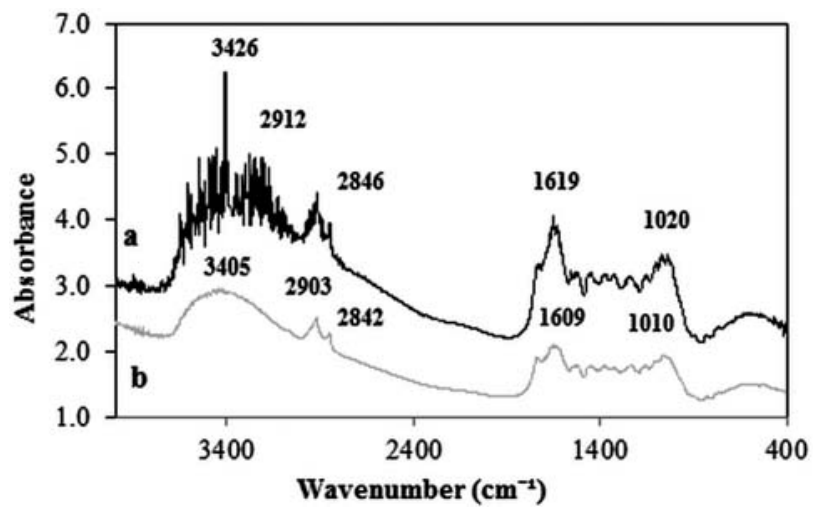

Figure 7. FTIR spectra of untreated WGT before adsorption (a) and after MG adsorption (b).

As it can see in Figure 7, the groups affected by the MG adsorption include $-\mathrm{OH}, \mathrm{N}-\mathrm{H}$ (stretching), secondary amines, $\mathrm{SO}_{3}$ (stretching), $-\mathrm{C}-\mathrm{C}-$, and amines groups. In the spectrum of untreated WGT biomass (before adsorption), Figure 7a, a broad band from 3600 to $3000 \mathrm{~cm}^{-1}$ for $-\mathrm{OH}$ groups of phenols/carboxyls was observed. The strong band attributed to the hydroxyl group (at 3426 $\mathrm{cm}^{-1}$ ) might be an indication of high cellulose content. After adsorption the aspect of this band is rather flat, and the maximum is shifted to $3405 \mathrm{~cm}^{-1}$, suggesting the MG adsorption onto WGT surface takes place. Alkane C-H vibrations were identified at 2919 and $2886 \mathrm{~cm}^{-1}$ for the untreated WGT before adsorption and shifted at 2903 and $2842 \mathrm{~cm}^{-1}$ for the WGT after adsorption fact which can be explained by the change in the lignocellulosic structure. ${ }^{16,54} \mathrm{~A}$ distinct band at $1619 \mathrm{~cm}^{-1}$ was observed, Figure 7, that was shifted at $1609 \mathrm{~cm}^{-1}$ after MG adsorption, band that was probably, the result of the stretching vibration of $\mathrm{C}=\mathrm{O}$ and $\mathrm{C}-\mathrm{N}$ (Amide I) peptidic bond of proteins. ${ }^{55}$ Bands at $1020 \mathrm{~cm}^{-1}$ (before adsorption) and $1010 \mathrm{~cm}^{-1}$ (after adsorption) that could be attributed to the stretching vibration of the $\mathrm{C}-\mathrm{O}$ groups, shifted after adsorption. The fingerprint region demonstrates the existence of sulfur or phosphate groups $\left(800-400 \mathrm{~cm}^{-1}\right)$.

All these changes identified in the FTIR spectra sup-

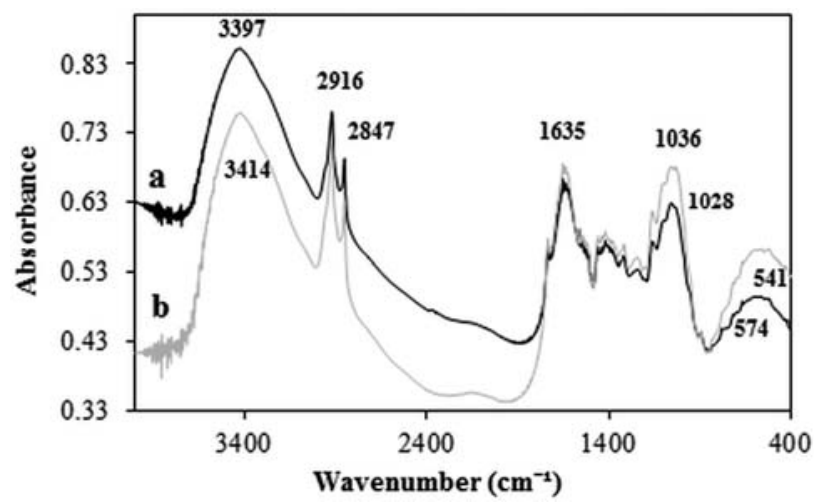

Figure 8. FTIR spectra of WGT treated with $\mathrm{NaOH}$ before adsorption (a) and after MG adsorption (b). port the fact that MG dye adsorption onto WGT surface occurred.

Spectra of $\mathrm{NaOH}$ treated WGT before and after MG dye adsorption are depicted in Figure 8 . The broad absorption peak at around $3397 \mathrm{~cm}^{-1}$ correspond to the $\mathrm{O}-\mathrm{H}$ stretching vibrations due to inter- and intra-molecular hydrogen bonding of cellulosic polymeric compounds (macromolecular associations), such as alcohols, phenols, and carboxylic acids, as in pectin, cellulose, and lignin, thus, showing the presence of hydroxyl groups on the adsorbent surface. ${ }^{47}$ After MG adsorption this band was shifted at $3414 \mathrm{~cm}^{-1}$, fact which supports the MG adsorption. The band at $2916 \mathrm{~cm}^{-1}$ is attributed to the $\mathrm{C}-\mathrm{H}$ stretching vibration of aliphatic acids, while the band at $1635 \mathrm{~cm}^{-1}$ is due to asymmetric stretching vibrations of $\mathrm{C}=\mathrm{O}$, from carboxyl acid groups. ${ }^{17,31}$ The other prominent band at $1028 \mathrm{~cm}^{-1}$ was shifted at $1036 \mathrm{~cm}^{-1}$ and is due to $\mathrm{C}-\mathrm{O}$ stretching vibration from cellulose. Moreover, in the case of treated WGT biomass after adsorption, a remarkable shift in positions of $-\mathrm{OH}$ and $\mathrm{C}=\mathrm{O}$ bands was observed, which indicates that MG is binded mostly at these groups. ${ }^{56-59}$ The changes in FTIR spectra confirm the binding of MG with functional groups present on the adsorbent surface. Similar observation were also reported by Pirbazari et al. ${ }^{25}$ The proposed adsorption mechanism would involve the connection realized between a lone pair of the oxygen atom in $-\mathrm{OH}$ and $\mathrm{C}=\mathrm{O}$ and the nitrogen atom $=\mathrm{N}^{+}\left(\mathrm{CH}_{3}\right)_{2}$ in the $\mathrm{MG}$ molecule.

\section{Conclusions}

The efficiency of waste green tea biomass in removing malachite green dye from aqueous solution has been investigated. The removal efficiency increases with the increase of biomass quantity until no further significant change was observed (4-5 g) and an increase in temperature, and hence the adsorption process is endothermic in nature. Six chemical treatments were tested (four acidic, one basic, and one oxidant) in order to study, first, the chemical groups responsible for the adsorption of MG onto WGT biomass, and secondly, which chemical treatment gives better results in terms of adsorption efficiency by comparison to the untreated material. For WGT biomass, the alkali $(\mathrm{NaOH})$ and acidic $\left(\mathrm{H}_{2} \mathrm{SO}_{4}\right.$, $\mathrm{H}_{3} \mathrm{PO}_{4}$, and tartaric acid) treatments led to increases of the adsorption effficiency from $89 \%$ (untreated WGT) to $92 \%$ $(\mathrm{NaOH}), 93 \%, 94 \%$ and $95 \%$ for acidic treatments (tartaric acid, $\mathrm{H}_{3} \mathrm{PO}_{4}$, and $\mathrm{H}_{2} \mathrm{SO}_{4}$, respecively).

It can be concluded that this green aproach, ecofriendly, and economic cellulosic biomass, could be a promising adsorbent in environmental pollution cleanup. Also, chemical treatments applied to lignocellulosic adsorbents, improved adsorption efficiencies. Further detailed economical analysis (eg. materials and operating costs) could be used in order to design practical engineering application in the future. 


\section{References}

1. M. T.Yagub, T. K. Sen, S. Afroze and H. M. Ang, $A d v$. Colloid Interface Sci., 2014, 209, 172-184. https://doi.org/10.1016/j.cis.2014.04.002

2. I. M. Banat, P. Nigam, D. Singh and R. Marchant, Bioresour. Technol., 1996, 58, 217-227. https://doi.org/10.1016/S0960-8524(96)00113-7

3. Z. Aksu, Process Biochem., 2005, 40(3-4), 997-1026. https://doi.org/10.1016/j.procbio.2004.04.008

4. B. H.Tan, T. T. Teng and A. K. M. Omar, Water Res., 2000, 34, 597-601. https://doi.org/10.1016/S0043-1354(99)00151-7

5. A. I. Zouboulis, N. K. Lazaridis and A. Grohman, Separ. Sci. Technol., 2002, 37, 403-416. https://doi.org/10.1081/SS-120000795

6. B. Bolto, D. Dixon, R. Eldridge, S. King and K. Linge, Water Res., 2002, 36, 5057-5065. https://doi.org/10.1016/S0043-1354(02)00231-2

7. L. Szpyrkowicz, J. Naumczyk and F. Zilio-Grandi, Water Res., 1995, 29, 517-524. https://doi.org/10.1016/0043-1354(94)00176-8

8. S. Esplugues, J. Giménes, S. Contreras, E. Pascual and M. Rodriguez, Water Res., 2002, 36, 1034-1042. https://doi.org/10.1016/S0043-1354(01)00301-3

9. P. Mavros, A. C. Daniilidou, N. K. Lazaridis and L. Stergiou, Environ. Technol., 1994, 15, 601-616. https://doi.org/10.1080/09593339409385467

10. S. Dawood and T. K. Sen, Water Res., 2012, 46, 1933-1946. https://doi.org/10.1016/j.watres.2012.01.009

11. I. H. Dakhil, J. Kerbala Univ., 2013, 1, 5-14.

12. C. Crini, Bioresour. Technol., 2006, 97, 1061-1085. https://doi.org/10.1016/j.biortech.2005.05.001

13. H. Ali, Water Air Soil Pollut., 2010, 213, 251-273. https://doi.org/10.1007/s11270-010-0382-4

14. A. Bhatnagar and M. Sillanpää, Chem. Eng. J., 2010, 157, 277-296. https://doi.org/10.1016/j.cej.2010.01.007

15. D. Podstawczyk, A. W. Krowiak, K. Chojnaka and Z. Sadowski, Bioresour, Technol., 2014, 160, 161-165. https://doi.org/10.1016/j.biortech.2014.01.015

16. N. S. Mokgalaka, R. I. McCrindle and B. M. Botha, J. Anal. Atom. Spectrom., 2004, 19, 1375-1378. https://doi.org/10.1039/b407416e

17. E. Akar, A. Altinişik and Y. Seki, Ecol. Eng., 2013, 52, 19-27. https://doi.org/10.1016/j.ecoleng.2012.12.032

18. N. T. Zaveri, Life Sci., 2006, 78, 2073-2080. https://doi.org/10.1016/j.lfs.2005.12.006

19. B. H. Hameed, J. Hazard. Mater., 2009, 161, 753-759. https://doi.org/10.1016/j.jhazmat.2008.04.019

20. M. Auta and B. H. Hameed, Chem. Eng. J., 2011, 171, 502-509. https://doi.org/10.1016/j.cej.2011.04.017

21. A. Fazal and U. Rafique, J. Water Sustain., 2012, 2(4), 259-270.

22. J. Shah, M. R. Jan, A. Ul Haq, and M. Zeeshan, J. Saudi Chem. Soc., 2015, 19, 301-310.

23. C. -H. Weng, Y. -T. Lin, D. -Y. Hong, Y. C. Sharma, S. -C.
Chen et al. Ecol. Eng., 2014, 67, 127-133. https://doi.org/10.1016/j.ecoleng.2014.03.053

24. A. E. Pirbazari, E. Saberikhah, M. Badrouh and M. S. Emami, Water Resour. Ind., 2014, 6, 64-80. https://doi.org/10.1016/j.wri.2014.07.003

25. S. Burcă, A. Măicăneanu and C. Indolean, Rev. Roum. Chim., 2016, 61(6-7), 541-547

26. http://www.pentachemicals.eu/specifikace/specifikace_ 892.pdf

27. W. Amey and V. N. Ganvir, Int. Res. J. Environ. Sci., 2013, 2, $53-55$.

28. J. Zhang, Y. Li, C. Zhang and Y. Jing, J. Hazard. Mater., 2008, 150, 774-782. https://doi.org/10.1016/j.jhazmat.2007.05.036

29. M. H. Kalavathy, T. Karthikeyan, S. Rajgopal and L. R. Miranda, J. Colloid Interf. Sci., 2005, 292, 354-362. https://doi.org/10.1016/j.jcis.2005.05.087

30. A. Ronda, M. A. Martín-Lara, M. Calero and G. Blázquez, Ecol. Eng., 2013, 58, 278-285. https://doi.org/10.1016/j.ecoleng.2013.07.013

31. R. Gnanasambandam and A. Protor, Food Chem., 2000, 68, 327-332. https://doi.org/10.1016/S0308-8146(99)00191-0

32. M. Suchy and D. S. Argyropoulos, Japan TAPPI J., 2002, 1, $1-18$.

33. M. -H., Baek, C. O. Ijagbemi, O. Se-Jin, D. -S. Kim, J. Hazard. Mater, 2010, 176, 820-828.

34. F. Deniz, and S. Karaman, Chem. Eng. J., 2011, 170, 67-74. https://doi.org/10.1016/j.cej.2011.03.029

35. S. Venkata Mohan, S. V. Ramaianah and P. N. Sharma, Biochem. Eng. J., 2008, 38, 61-69. https://doi.org/10.1016/j.bej.2007.06.014

36. A. Saeed, M. Sharif and M. Iqbal, J. Hazard. Mater, 2010 , 179, 564-572. https://doi.org/10.1016/j.jhazmat.2010.03.041

37. W. Yang, S. Yajuan, L. Ping and L. Bo, J. Chinese Inst. Food Sci. Technol., 2011, 4, 83-89.

38. Liu, L., Liu, J., Li, H., Zhang, H., Liu, J. and Zhang, H., BioResources, 2012, 7(3), 3555-3572.

39. D. M. Gligor, and A. Maicaneanu, In Clay: Types, Properties and Uses, edited by Humphrey J. P.; Boyd D. E.; Hauppauge, NY: Nova Science Publishers Inc., 2011, pp. 1-62.

40. M. Macoveanu, D. Bilba, N. Bilba, M. Gavrilescu, and G. Soreanu, Procese de schimb ionic în protecţia mediului; Bucharest: Matrix Rom, 2002.

41. M. A. Hossain and Md. L. Hossain, Int. J. Adv. Res., 2014, 2 , 360-374.

42. Y. Liu and Y. J. Liu, Sep. Purif. Technol., 2008, 61, 229-242. https://doi.org/10.1016/j.seppur.2007.10.002

43. E. Pehlivan, T. Altun and Ş. Parlayici, Food Chem., 2012, 135, 2229-2234. https://doi.org/10.1016/j.foodchem.2012.07.017

44. R. Abdallah and S. Taha, Chem. Eng. J., 2012, 195-196, 69-76. https://doi.org/10.1016/j.cej.2012.04.066

45. L. W. Low, T. T. Teng, N. Morand and B. Azahari, APCBEE Procedia, 2012, 1, 103-109. https://doi.org/10.1016/j.apcbee.2012.03.018 
46. Y. Feng, H. Zhou, G. Liu, J. Qiao, J. Wang, H. Lu, L. Yang, and Y. Wu, Bioresource Technol., 2012, 125, 138-144. https://doi.org/10.1016/j.biortech.2012.08.128

47. H. Yazici, M. Killç, M. Solak, J. Hazard. Mater., 2008, 151, 669-675. https://doi.org/10.1016/j.jhazmat.2007.06.042

48. N. Gupta, A. K. Kushwaha and M. C. Chattopadhyaya, Arabian J. Chem., 2016, 9, S707-S716. https://doi.org/10.1016/j.arabjc.2011.07.021

49. K. G. Bhattacharyya and A. Sharma, J. Hazard. Mater., 2004, 113, 97-109. https://doi.org/10.1016/j.jhazmat.2004.05.034

50. A. P. Batista, L. P. Romão, M. L. Arguelho, C. A. Garcia, J.P. Alves et al., J. Hazard. Mater., 2009, 163, 517-523. https://doi.org/10.1016/j.jhazmat.2008.06.129

51. T. Gu, Green Biomass Pretreatment for Biofuels Production; Ohio: Springer, 2013. https://doi.org/10.1007/978-94-007-6052-3

52. A. Wankhade and V. N. Ganvir, Int. Research J. Environ. Sci., 2013, 2-4, 53-55.
53. G. Blázquez, M. Calero, A. Ronda, G. Tenorio, and M. A. Martín-Lara, J. Ind. Eng. Chem., 2014, 20, 2754-2760. https://doi.org/10.1016/j.jiec.2013.11.003

54. H. Eroglu, E. Varoglu, S. Yapıcı and A Sahın, Chem. Eng. J., 2010, 165, 563-572. https://doi.org/10.1016/j.cej.2010.09.074

55. Z. Chen, H. Deng, C. Chen, Y. Yang, and H. Xu, J. Environ. Health Sci. Eng., 2014, 12, 63-73. https://doi.org/10.1186/2052-336X-12-63

56. J. -F. Gao, Q. Zhang, J. -H. Wang, X. -L. Wu, S. -Y. Wang et al. Bioresource Technol., 2011, 102, 805-813. https://doi.org/10.1016/j.biortech.2010.08.119

57. P. Thamilarasu and K. Karunakaran, Canadian J. Chem. Eng., 2013, 91, 9-18. https://doi.org/10.1002/cjce.20675

58. A. Cabuk, S. Ilhan, C. Filik and F. Caliskan, Turk. J. Biol., 2004, 29, 23-28.

59. J. R. Njimou, A. Măicăneanu, C. Indolean, C. P. NanseuNjiki, E. Ngameni, Environ. Technol., 2016, 37, 1369-1381. https://doi.org/10.1080/09593330.2015.1116609

\section{Povzetek}

Proučevana je bila adsorpcija barvila malahitno zeleno (MG) iz vodne raztopine na odpadno biomaso zelenega čaja (WGT). Izvedena je bila serija šaržnih eksperimentov z namenom ugotoviti vpliv temperature in količine biomase na adsorpcijo. Maksimalna kapaciteta odstranitve z neobdelano biomaso WGT je bila $89 \%$ (4 g biomase, 100 mL raztopine s koncentracijo $94 \mathrm{mg} / \mathrm{L}, 316 \mathrm{~K}$ ), pri tem se je kapaciteta adsorpcije večala od 296 do 316 K.Izračunanitermodinamskiparametri $\left(\Delta \mathrm{H}^{\circ}, \Delta \mathrm{S}^{\circ}, \Delta \mathrm{G}^{\circ}\right) \mathrm{kažejo,} \mathrm{da} \mathrm{je} \mathrm{adsorpcijaendotermna} \mathrm{in} \mathrm{nespontana.} \mathrm{Testiranih} \mathrm{je} \mathrm{bilo} 6$ kemijskihpredobdelavbiomase $\left(\mathrm{H}_{3} \mathrm{PO}_{4}, \mathrm{H}_{2} \mathrm{SO}_{4}, \mathrm{HCl}\right.$, vinska kislina, $\mathrm{H}_{2} \mathrm{O}_{2}$ in $\left.\mathrm{NaOH}\right) \mathrm{z}$ namenom ugotoviti skupine, odgovorne za adsorpcijo. Obdelava $\mathrm{z} \mathrm{NaOH}$ in $\mathrm{H}_{3} \mathrm{PO}_{4}$ je povečala adsorpcijsko kapaciteto na $92 \%$ in $95 \%$. FTIR spektroskopija je pokazala modifikacijo površine biomase in s tem vpliv na adsorpcijo. 